Article

\title{
Boards that Make a Difference in Firm's Acquisitions: The Role of Interlocks and Former Politicians in Spain
}

\author{
Santiago Kopoboru *, Gloria Cuevas-Rodríguez and Leticia Pérez-Calero—(1) \\ Department of Business Administration and Marketing, Faculty of Business, Universidad Pablo de Olavide, \\ 41013 Seville, Spain; gcuerod@upo.es (G.C.-R.); lcalero@upo.es (L.P.-C.) \\ * Correspondence: skopagu@upo.es
}

Received: 23 December 2019; Accepted: 22 January 2020; Published: 29 January 2020

\begin{abstract}
This study examines the influence of board interlocks and former politicians on decisions regarding acquisitions in Spain. Our research suggests that board interlocks to other firms can positively influence operations in terms of acquisition scale. Our findings also show that this relationship is positively moderated by the presence of former politicians. That is, the effects of interlocks on acquisitions are amplified further when there are former politicians on boards, which confirms their role as community influentials. In the case of Spain, and under-regulated industries, this complementary effect is maintained. However, the role played by interlocks seems to be more important than former politicians, which means that board interlocks can replace other formal methods of acquiring information (through former politicians) while attempting acquisitions.
\end{abstract}

Keywords: board interlocks; former politicians; regulated industries; acquisitions

\section{Introduction}

Board interlocks, which take place "when a person affiliated with one organization sits on the board of directors of another organization" [1] (p. 271), have become one of the main indicators of social ties among firms. Their prevalence is very high and their increasing number cannot be ignored [2-4].

The literature on corporate governance suggests that the use of board interlocks may be a corporate board mechanism used to gain access to other companies [3] and to obtain more accurate information [5], which improves firm performance [6]. From a Resource Dependence Theory [7], organizations are not self-sufficient but depend, to some extent, on external elements. Organizations can use board interlocks as a way to create links with their dependent sources and to reduce uncertainty. Board ties to other firms provide a unique opportunity for directors to exchange information, to observe the business practices of their peers, create new business opportunities, and to obtain general business information $[1,8,9]$. Thus, research has shown that corporate practices that are shared among firms via board interlocks tend to have an impact on the dissemination of innovation [10-13], diversification strategies [4], the adoption of golden parachutes and social corporate responsibility practices [14], stock options and poison pills [15,16], as well as the creation of joint ventures [17] and the adoption of multidivisional organization forms [18].

Consistent with the above-mentioned research, we contend that boards that are well connected to other firms provide access to information that is relevant in firm acquisitions. This increases the likelihood of acquisition by the company. Although previous literature has analysed the effect of board ties to other firm behaviours or performances on acquisition, the main object of study has been the financial outcomes of acquisitions [19-22]. We also explore whether having former politicians on the board has an impact on this relationship. In this sense, we go beyond the mere exploration of the direct effect of interlocks on acquisition strategies motivated by the evidence that other board networks, such as ties to the government, could influence strategic choices [23-25]. Indeed, it is certainly true 
that the main criticism that interlock research has received is that board interlocks do not capture the complexity and richness of inter-firm networks [26]. The influence of interlocks in acquisition strategies can, therefore, vary depending on other board connections present within the board. Our research goes one step further with regards to questioning the initial assumption that the more interlocked the boards, the more beneficial for acquisitions, and we try to provide insight into the specific conditions under which an interlocked board can be beneficial or detrimental for a firm's acquisitions [27].

Thus, while there is a broadly assumed relationship between economic power and political influence, our research analyses the influence of politicians on a specific management decision: a firm's acquisition. One of the reasons why there is scarce or no research on this area is the difficulty of both measuring corporate political activity and evaluating its consequences. This topic has been filled with controversy lately, especially because of the discussion on the existing "revolving doors" and the need to promote responsible corporate behaviours. In the end, the engagement of firms on sustainability depends on their lobbying positions and on external memberships.

Further, we acknowledge that the characteristics of the industry's environment clearly affects effective board decision making surrounding acquisitions [28-30]. The relationship between board networks (interlocks and former politicians) and the scale of acquisitions may vary depending on the regulation of the industry in which the acquirer firm is active [31,32]. Because the prospects for effective acquisitions depend, to a great extent, on the directors' ability to design an agreement that passes regulatory scrutiny [25], our focus is on government control across industries.

Accordingly, drawing on the resource provision role of the board, we explore the following research questions: (a) Do networked boards via interlocks influence decisions on acquisitions? (b) Do networked boards via former politicians moderate the board interlocks-acquisitions relationship? (c) Does the degree of regulation of the industry affect these relationships (i.e., (a) and (b))?

In order to answer these research questions, we examined the population of non-financial firms listed in the Spanish Stock Exchange over the period 2010-2015. Our results illustrate how well-connected boards (with a high number of board interlocks and former politicians as directors) have an informational advantage over those boards without such ties and how it leads to higher motivation of the company to acquire. Also, they show that under highly regulated conditions, these informational advantages are even more advantageous to make decisions on acquisitions.

The main contributions of our research are the following: first, we aim to provide a better understanding of the influence of inter-firm board networks on acquisition decisions, suggesting which characteristics of the board (in terms of board interlocks and political connections) can provide useful information and access to outside stakeholders (other companies and the government) for firms making decisions. The literature on interlocks $[21,28]$ and on former politicians on boards $[25,30,33]$ has generally been addressed separately. In this study, however, we conducted a holistic perspective analysing both variables.

Second, we develop our research in one continental European country, Spain. Previous studies on board networks have mostly been carried out within the Anglo-American context or have adopted an international perspective. This fact may have influenced the interpretation of the results in previous studies because of the existing legal, judicial, and cultural differences across countries [34-37]. The very few studies that have been conducted in Spain have focused on the relationship between political connections and compensation policies in saving banks, the informativeness of accounting earnings [38], and the importance of hiring influential former politicians in the revolving doors [39].

Third, we analyse the acquisition decision with regards to its scale, measured in terms of the acquisition value and the percentage of acquired shares. Most of the studies analysing how corporate governance mechanisms affect the acquisition have focused on financial outcomes (e.g., deal announcements on abnormal returns) [19,27,40-42].

Fourth, we shed light on how board networks can provide resources that are helpful to the firm in adopting strategic decisions such as acquisitions. In this sense, this research provides a deeper 
understanding of the Resource Dependency Theory [7], suggesting that better connected boards provide reliable and private information and reduce the uncertainty related to acquisition processes.

The paper is organized as follows. Section 2 reviews previous research on the field. This leads to the hypothesis, followed by the methodology used and the sample. Next, the findings are presented, followed by a final discussion and the conclusions.

\section{Materials and Methods}

\subsection{Theoretical Background and Hypotheses}

Among the business strategies with the highest level of uncertainty, the literature has identified business acquisitions. Decisions on acquisitions are quite often associated with industry-level shocks $[43,44]$ that involve environmental uncertainty. Despite this uncertainty and a substantial decrease in takeover activity during the financial crisis, acquisitions have reached new heights all over the world [22]. This fact has caused a shift of focus in the literature [45], now oriented towards the study of how the characteristics of the board, such as board independence [41,46,47], board size [48], board meetings, or board ownership, affect the propensity to acquire other firms [49]. In contrast, we focused on the importance of interlocks and former politicians on firms' acquisitions.

The basic Spanish legal framework for corporate acquisitions, mergers, and other types of corporate reorganisation is mainly contained in the Spanish Civil and Commercial Codes. These Codes specifically foresee the general principle that governs private transactions in general and merger and acquisitions (M\&A) in particular: the free will of the parties. The contracting parties may establish any covenants, clauses, and conditions that they deem convenient, provided that they are not contrary to the laws, moral or public order [50].

Based on this, M\&A transactions are structured in many different forms, most often driven by the underlying tax structures of the buyer, the characteristics of the asset to be acquired, or the regulated status of the company to be acquired. The most common structures found in the Spanish M\&A transactions are "share deals", "asset or debt for equity deals", or "leveraged buyouts" (LBOs) [51]. The M\&A deal market recovered in Spain in the period 2010-2015 because of cheap financing, the growth of expectations over the Spanish economy, and the political stability of the country. Companies in the energy, mining, and utilities sectors attracted a number of important deals (Deloitte M\&A Index 2016 [52]).

\section{Board Interlocks and Acquisitions}

Previous literature has analysed the effect of board ties to other firms' behaviours or performances on acquisition. Thus, $[10,23]$ showed that the number and types of acquisitions made by a focal firm are linked to the acquisitions made by its interlocked partners. Cai and Sevilir [21], in contrast, found that connections between the acquirer and target boards (i.e., sharing common directors) led to higher acquirer announcement period abnormal returns. Ishii and Xuan [53], in turn, contend that the existence of social ties between boards (of both the acquirer and the target firms) has a positive effect on the target firms' likelihood to be subsequently divested for performance-related reasons. Using social network methods, Singh and Schonlau [20] show that central firms are more likely to participate in merger activities and tend to have better post-acquisition performance than non-central firms in the network. Cai and Sevilir [21] also conclude that when the acquirer and the target firm share directors, there is a number of benefits to the acquirer, such as higher announcement returns, lower takeover premiums, and greater value creation. Other studies have examined how directors with investment banking experience exert their influence on a firm's acquisition behaviour [ $[54,55]$.

In line with Gulati and Westphal [17], we support the idea that board interlocks can be an important source of information for directors regarding acquisition decisions. Obviously, board interlocks are not the only source of information available [28], but scholars have emphasised the value of said direct 
communication between fellow corporate leaders, and they suggest that it is particularly influential because it comes from a reliable source $[10,15]$.

Despite their recent growth, acquisitions are associated with a variety of risks and pitfalls that result in considerable uncertainty about the acquisition decision. This uncertainty comes from different sources, such as the difficulties of organizations to obtain information about the identification and competencies of their actual targets [22,56]. For example, if a bidding firm has a better understanding of the potential target firm's capabilities, potential post-acquisition economies of certain scope or scale, or possible related synergies, they will be able to evaluate the potential acquisition better and more efficiently by reducing information asymmetries $[57,58]$. However, this information is confidential, potentially costly to obtain, and may not be revealed outside close relationships. Renneboog and Zhao [24] show that interlocking directorships help bidders to identify targets, increase the probability of acquisition completion, and reduce the duration of negotiations. It seems that board interlocks can provide reliable and possibly private information about the target firms that definitely affect the bidding process. By means of board interlocks, directors can learn from their experience in other firms' acquisitions [59-61], avoid previous mistakes and, in sum, be in a better position to prepare and negotiate the bidding acquisition process.

As a whole, we believe that board interlocks may act as a channel of information that enables directors to acquire first-hand knowledge of other firms' capabilities, activities and plans, and provide this information in a timely manner, reducing the acquisition uncertainty mentioned above. We expect all this to lead to large-scale acquisitions, so that the higher the interlocked boards of acquirer firms, the larger the acquisition scale.

Based on this, we propose the following hypothesis:

$\mathbf{H}_{\mathbf{1}}$. Interlocked boards of acquirer firms are positively associated with large-scale acquisitions.

\subsection{Former Politicians on Boards and Acquisitions}

Nowadays, there is a debate on what has been called "revolving doors", or private corporations' (e.g., on boards of directors) tendency to hire politicians that have held relevant political positions in the government [62]. This creates ethical and deontological problems given by the clear overlap of "what is public" and "what is private" [63]. In this respect, there has been pressure on, and concern of, legislators to increase transparency and good corporate governance codes that make corporations responsible for reporting the identity of their board members.

Studies in connection therewith that have analysed the benefits obtained from firms' political connections have been conducted in emerging countries with high levels of corruption [64]. However, studies on the impact of former politicians on boards in developed countries is scarce, with the exception of the research conducted in the United States, which suggests their beneficial effect. Agrawal and Knoeber [65] and Goldman et al. [66], for instance, argue that political connections can help firms to better understand public policies and bureaucratic procedures. Indeed, former politicians might possess information on pending legislation or the workings of the legislative process. Hillman [31] argues that these political connections can provide a direct channel to existing politicians and provide legitimacy to the firm by associating the reputation and status of these politicians with the firm. Faccio [67] also points out that political connections can lead to preferential treatment by the government by helping firms to win government contracts, extract concessions, lower tax rates, reduce regulatory oversight over the connected firm, or provide access to external financing, among others. The benefit of gaining access to capital from financial institutions has also been supported by Khwaja and Mian [68] as well as Yeh et al. [69]. Other studies have found a positive relationship between political connections and stock returns, and future performance of US firms [70], as well as positive market reaction [66]. Among the few studies that have examined the value of political connections in other developed markets are Amore and Bennedsen [71] in Denmark, Niessen and Ruenzi [72] in Germany, and Bona-Sánchez et al. [38] and García-Meca and Palacio [73] in Spain. The latter, 
in particular, analysed the effect of political connections on accounting performance, informativeness of accounting earnings, and firm reputation

It is in this context that we attempt to analyse this "lobbying effect" that former politicians have when they sit on boards, and their potential added value to the firm [63]. In terms of the board members' taxonomy by Hillman et al. [74], former politicians play the role of community influentials, and this role is different from that of business experts or support specialists. Moreover, it provides necessary non-business perspectives on proposed strategies, as well as has influence on powerful groups in society.

The resources provided by former politicians are especially valuable in acquisition operations. Thus, Ferris et al. [25] suggest that the appointment of former politicians to boards increases the likelihood to acquire targets and avoid regulatory delay or denial. It also increases merger premiums and enjoys higher post-merger financial and operating performance. According to these authors, the benefits of political connections are basically twofold: (1) former politicians are likely to have insider information concerning merger processes or reviewing agencies' practices, and (2) acquiring firms can deal with the regulatory barriers of federal agencies more easily thanks to their former politicians' government networking. As merging firms can provide future employment opportunities, campaign contributions, and other benefits to current regulators, the interlocks of former politicians could be seen as beneficial and/or could favour exchange [75-77].

Based on the above-mentioned literature, we contend that the existence of former politicians and their networking activity may have an impact on the decision of acquisition of firms leading to large-scale acquisitions. Thus, we define the following hypothesis:

$\mathbf{H}_{2}$. The interaction between interlocks and former politicians on boards are positively associated with large-scale acquisitions.

\subsection{Regulated Industries}

One of the most relevant factors organizations face is the government. Governmental entities control nearly every aspect that affects business life-policy, regulations, and laws [3,78]—which encourage firms to keep informed about government regulations, policies, and emerging public policy issues [78] to address some strategic operations, including acquisitions.

The existence of interlocks brings about benefits for the company in highly regulated sectors because they play an important role in ensuring external resources through their linkages to other firms in the external environment [4] and in the ability to interpret such regulation [79]. In fact, there is evidence in the literature that the level of networking increases under regulation, as the level of interlock ties in regulated sectors is higher than that in companies from other sectors $[79,80]$. Similarly, there are some advantages for firms that appoint former politicians to the board, and they seem to increase under elevated levels of regulatory scrutiny $[31,65,76,81,82]$. By means of the presence of these directors, firms can influence rule making and gain access to timely information about government contracts, industrial and trade policies, and changes in regulatory policies and enforcement [83]. In other words, former politicians bring unique resources to the firm, which allow the firm to gain knowledge of the regulatory environment [31].

Taking the above benefits into consideration, we expect a positive association of interlocks, politicians, and large-scale acquisitions under regulated industries. That is to say, when the environment is highly regulated, firms with more interlocks and former politicians in their boards are associated with large-scale acquisitions. In a highly regulated context, firms will be tempted to acquire more when they feel they have access to information of other companies (through imitation of strategies) derived from having more interlocks on the board [10,28], but also when they have access to knowledge of internal governmental mechanisms $[83,84]$ to better understand the public policy process [32] in favour of their acquisitions. Also, politicians on boards can reduce regulatory requirements around acquisitions under highly regulated sectors [85], offering firms the ability to network or lobby with current regulators or politicians [25]. 
Hence, based on the above arguments, we define the following hypothesis:

$\mathbf{H}_{3}$. There is a three-way interaction between the government control across industries, interlocks, and former politicians on boards on the scale in acquisitions. As the government control across industries increases, interlocked and political experienced boards are more positively associated with large-scale acquisitions.

\subsection{Methodology}

\subsubsection{Sample and Data Collection}

The sample comprised all the acquisitions completed by a number of publicly held companies that were Spanish-based between January 1, 2010 and December 31, 2015. The sample of acquisitioin was created using the AMADEUS database (a database with financial information about European firms). The first step was to search Spanish firms in the Madrid Stock Exchange that were quoted on the continuous market during the period 2010-2015. After searching all the acquisitions made by these companies, it was found that a total of 94 out of 175 companies made acquisitions during the period 2010-2015, and 68 made more than one acquisition during this period. Thus, the final dataset included 479 acquisitions that occurred within the time period starting in 2010 and ending in 2015, and whose acquirers were companies listed on the continuous market. This database also included information about board members. Boards of directors are one of the many resources firms have, and they serve two important functions within a firm: monitoring and advising $[22,86,87]$. Following Daily et al. [88] (p. 371), "we define governance as the determination of the broad uses to which organizational resources will be deployed and the resolution of conflicts among the myriad participants in organizations". On the one hand, boards monitor management on behalf of shareholders, and on the other, they provide resources to the firm $[87,89]$. The board provides valuable advice to management and monitors its policies [90]. In general, board analysis has focused on board composition and board size [73,91,92]. Using agency theory [93,94], board composition classifies board members as outsiders or insiders. Insiders are members of the board who also have a managerial role in the firm. Outsiders are non-managerial members of the firm and non-executive directors, and their functions include monitoring the CEO and management on behalf of shareholders and providing resources, such as knowledge and advice, to the firm $[89,95,96]$. Our database identified by name all the board members of the analysed firms as well as their standing (outsider/insider).

\subsubsection{Dependent Variables}

In this study, the scale in acquisitions was measured by means of two dimensions: the size of the deal value and the percentage of the acquired stake. Both of these dimensions represent the "depth" of the firm's participation in the acquired firm. Given the different measures of the variables, to calculate the composite variable "scale in acquisitions", their standardised values were estimated, and afterwards their average value was calculated.

Most of the literature used to measure the impact that acquisitions have is on market value $[21,48,53,97]$ or accounting performance of the acquirer firms [25]. Very few studies have been conducted on the strategic aspect of the acquisition operation, such as (1) non-diversifying operations, when the target is in the same industry as the acquirer, versus diversifying operations, when the target is not in the same industry as the acquirer [25]; (2) market-oriented acquisitions versus public bidding [30]; or (3) the duration of the acquisition agreement [24]. This study tries to delve into these strategic aspects, including the scale in acquisitions, and proposes that these strategic decisions are driven by the board of directors.

\subsubsection{Independent Variables}

Interlocks are defined as the ties that are formed when a board member serves on the board of another firm. This measure of interlocks has previously been examined in the literature on boards $[96,98-100]$. The term "director interlocks" referred to the total number of external ties with 
other firms that are formed by a board of directors. The total number of interlocks is calculated as the total number of external ties formed by directors of the acquirer firm with other firms divided by the board size of the acquirer firm. The information about interlocks was obtained from corporate governance annual reports published by the Comisión Nacional del Mercado de Valores (the Spanish Stock Market Commission, or CNMV). These reports provided information about the names of all the board members for each firm in our sample.

The term "politicians on board" $[31,38]$ was used to measure the number of directors with political experience on each acquirer firm. The board of directors of the companies was examined for the number of directors with political (elected or appointment) experience at the local, state, or national level. First, using corporate governance reports, we created a database with all the names of board members in the firms under examination in the given period. Secondly, using public sources such as websites, we created a database with data from 1975 to 2014 with a list of members of the Spanish Parliament and Senate, regional parliaments, state secretariats, and the European Parliament. This included prime ministers, cabinet ministers, members of parliament, senators, secretaries of state, members of any of the regional parliaments in Spain, and members of any local government in Spain. Officials elected internationally include members of the European Parliament as well as members of different foreign parliaments. We cross-referenced both databases. The result was a list of board members who had also been elected as political representatives. Finally, we also searched magazine articles about the links established between politicians and private firms. This search provided information about former politically appointed civil servants who were board members.

Finally, we included the degree of regulation in the industry $[31,32]$ through a dichotomous variable that took value 1 when the industries of the acquirer firms were heavily regulated by the government, and 0 otherwise. Highly regulated sectors have traditionally been the utilities sector (mainly electricity), where pricing and even profits are regulated by the state [65], as well as banking and financial services [101,102] and the chemicals sector [103]. All other sectors in our sample would be barely regulated sectors. Therefore, we included two groups with substantially different regulatory environments.

\subsubsection{Control Variables}

Based on other studies on corporate governance, we included the following control variables that might affect the proposed relations. First, to control for firm-level tendencies to acquire, we used firm size and a firm's previous performance. Firm size was measured by considering the number of employees in each acquirer firm for each year [21], and a firm's previous performance was measured by means of previous returns on assets (ROAs) of the acquirer firms [25,28]. Also, we included board-level characteristics of the acquirer firms that could influence the scale of acquisitions, such as board size [21], measured as the number of directors on the board, and percentage of non-executive directors [21], calculated as the sum of non-executive directors on each board divided by the total number of board members.

Given that several theories on acquisitions have proposed that industry conditions affect the activity on acquisitions [28], we controlled for two industry variables. First, to control for synergies between the acquirer and the target, we used diversifying acquisition, measured as a dummy variable, and coded it as 1 if both the acquirer and target firm shared the same 2-digit NACE codes (Statistical Classification of Economic Activities in the European Union), and 0 otherwise [21,25]. When the business activities of the acquiring and target firms are similar, the acquirer will be prone to acquire new firms. Second, we controlled industry velocity of the target firm measured by the log of new companies that entered the industry annually. Industry velocity is a source of environmental or competitive uncertainty [7], as some industries more attractive to the acquirers than others.

Finally, we controlled for time and company "year", as well as effects including two dummy variables for each year of acquisition and acquirer company [23,28]. 


\section{Results}

Table 1 shows a summary of the descriptive statistics of the study variables and the correlation matrix between variables. All VIFs (Variance Inflation Factors, used check for multicollinearity), were substantially lower than 2 , with an average VIF of 1.38, suggesting that multicollinearity did not seem to be a problem.

We estimated our theoretical model by ordinary least-squares regression (OLS) with Stata/SE 12.0 using a robust model to account for heteroscedasticity. Table 2 includes the OLS regression results. In the baseline model (Model 1), we introduced the control variables. Models 2 to 6 were designed to test the proposed hypotheses, with Model 2 explaining 17.2\% of the variance scale of acquisition. This percentage increased through the models, rising to slightly above $28.1 \%$ in Model 6 . Overall, there was an increase in significance across models. The joint significance test of our explanatory variables also showed that the variables were significantly different from 0 in all models.

Hypothesis 1 predicts that there will be a positive relationship between interlocked boards and the scale of acquisitions. As shown in Model 2 and in Table 2, the coefficient was significant and positive (B = 0.04, $p<0.05)$; therefore, $\mathrm{H} 1$ was supported.

According to Hypothesis 2, we would expect that the interaction between interlocked and political experienced boards is positively associated with a larger scale in acquisitions. We modelled it by introducing the interaction between the interlocks variable and politicians on boards. The results obtained in Model 4 (Table 2 ) confirmed this expected moderation $(\mathrm{B}=0.00, p<0.01)$. To illustrate significant two-way interactions, we used STATA margins commands [104] and displayed the plots in Figure 1. Plots used the interaction terms for maximum and minimum values of interlocks and politicians on boards. Figure 1 illustrates that, as the percentage of politicians on boards increased, the previous positive association between percentage of interlocks and the scale of acquisitions became more positive.

Model 6 confirms Hypothesis 4. In particular, there was a three-way interaction between the degree of regulation, interlocked boards, and political experienced boards on the scale in acquisitions, as the coefficient for the three-way interaction was positive and significant $(\mathrm{B}=0.08, p<0.01)$. This coefficient was between confidence intervals with small standard errors. This coefficient indicated that the degree of government control in the industry increased the interaction effect between the interlocks variable and politicians on boards, as presented in Hypothesis 3. To illustrate this significant three-way interaction, we used STATA margins commands [104] and displayed the plots in Figure 2. This showed that the relationship was positive as long as interlocks and the number of politicians were high. Also, it further indicated that these two conditions together resulted in larger acquisitions, while the degree of government control in the industry increased. Table 3 shows that the slope difference test was significant. 
Table 1. Descriptive statistics and correlation matrix.

\begin{tabular}{|c|c|c|c|c|c|c|c|c|c|c|c|c|c|}
\hline Variables & Mean & SD & 1 & 2 & 3 & 4 & 5 & 6 & 7 & 8 & 9 & 10 & 11 \\
\hline 1. Scale in acquisitions & 0.00 & 0.70 & 1 & & & & & & & & & & \\
\hline 2. Interlocks & 1.61 & 1.37 & 0.06 & 1.00 & & & & & & & & & \\
\hline 3. Politicians on board & 10.66 & 11.65 & -0.06 & -0.06 & 1.00 & & & & & & & & \\
\hline 4. Government control & 0.24 & 0.43 & 0.07 & $-0.13^{* * *}$ & $-0.11^{* *}$ & 1.00 & & & & & & & \\
\hline 5. Log firm size & 6.08 & 2.24 & 0.04 & -0.08 & 0.04 & $0.27^{* * *}$ & 1.00 & & & & & & \\
\hline 6. Firm's previous performance & 3.22 & 20.97 & -0.05 & $0.11^{* *}$ & -0.02 & 0.04 & 0.01 & 1.00 & & & & & \\
\hline 7. Board size & 13.54 & 3.72 & -0.07 & 0.02 & $0.28^{* * *}$ & $0.17^{* * *}$ & $0.21^{* * *}$ & -0.08 & 1.00 & & & & \\
\hline 8. Percentage of non-executive directors & 0.82 & 0.11 & 0.03 & $-0.13^{* * *}$ & 0.04 & -0.07 & $0.20^{* * *}$ & $-0.17^{* * *}$ & $0.10 *$ & 1.00 & & & \\
\hline 9. Log industry velocity & 3.91 & 2.08 & -0.07 & $0.13^{* * *}$ & 0.00 & $-0.62 * * *$ & $-0.23^{* * *}$ & 0.05 & $-0.09 *$ & 0.02 & 1.00 & & \\
\hline 11. Company effects & - & - & 0.04 & $0.12 * *$ & -0.02 & $-0.42^{* * *}$ & $0.23^{* * *}$ & -0.04 & $-0.17^{* * *}$ & 0.04 & $0.39 * *$ & $-0.08 *$ & 1.00 \\
\hline
\end{tabular}

Note: number of observations $=479$. ${ }^{*} p<0.10$; correlations greater than 0.11 (or lower than -0.11 ) are significant at ${ }^{*} p<0.10$; ${ }^{* *} p<0.05$; correlations greater than 0.13 (or lower than -0.13 ) are significant at ${ }^{* * *} p<0.01$

Table 2. Regression analysis of the interlocks, politicians on board, and degree of regulation of the industry on scale in acquisitions.

\begin{tabular}{|c|c|c|c|c|c|c|}
\hline Control Variables and Independent and Moderating Variables & Model 1 & Model 2 & Model 3 & Model 4 & Model 5 & Model 6 \\
\hline \multicolumn{7}{|l|}{ Control variables } \\
\hline Log firm size & $\begin{array}{c}0.01 \\
(0.02)\end{array}$ & $\begin{array}{c}0.01 \\
(0.02)\end{array}$ & $\begin{array}{c}0.01 \\
(0.02)\end{array}$ & $\begin{array}{c}0.01 \\
(0.02)\end{array}$ & $\begin{array}{c}0.01 \\
(0.02)\end{array}$ & $\begin{array}{c}0.01 \\
(0.02)\end{array}$ \\
\hline Firm's previous performance & $\begin{array}{c}0.00 \\
(0.00)\end{array}$ & $\begin{array}{l}0.00 * \\
(0.00)\end{array}$ & $\begin{array}{l}0.00 * \\
(0.00)\end{array}$ & $\begin{array}{c}0.00 \\
(0.00)\end{array}$ & $\begin{array}{l}0.00 \text { ** } \\
(0.00)\end{array}$ & $\begin{array}{c}0.00 \\
(0.00)\end{array}$ \\
\hline Board size & $\begin{array}{l}-0.26 \\
(0.13)\end{array}$ & $\begin{array}{c}-0.27^{* *} \\
(0.13)\end{array}$ & $\begin{array}{l}\text { v0.24* } \\
(0.14)\end{array}$ & $\begin{array}{c}-0.30^{* *} \\
(0.15)\end{array}$ & $\begin{array}{c}-0.25 \text { * } \\
(0.14)\end{array}$ & $\begin{array}{l}-0.36 \\
(0.14)\end{array}$ \\
\hline Percentage of non-executive directors & $\begin{array}{c}0.00 \\
(0.00)\end{array}$ & $\begin{array}{c}0.00 \\
(0.00)\end{array}$ & $\begin{array}{c}0.00 \\
(0.00)\end{array}$ & $\begin{array}{c}0.00 \\
(0.00)\end{array}$ & $\begin{array}{c}0.00 \\
(0.00)\end{array}$ & $\begin{array}{c}0.00 \\
(0.00)\end{array}$ \\
\hline Log industry velocity & $\begin{array}{c}0.00 \\
(0.00)\end{array}$ & $\begin{array}{l}0.00 * \\
(0.00)\end{array}$ & $\begin{array}{l}0.00 * \\
(0.00\end{array}$ & $\begin{array}{l}0.00 * * \\
(0.00)\end{array}$ & $\begin{array}{l}0.00 * \\
(0.00)\end{array}$ & $\begin{array}{c}0.00 \\
(0.00)\end{array}$ \\
\hline Temporal effects & $\begin{array}{c}0.01 \\
(0.03)\end{array}$ & $\begin{array}{c}0.00 \\
(0.00)\end{array}$ & $\begin{array}{c}0.00 \\
(0.00)\end{array}$ & $\begin{array}{c}0.00 \\
(0.00)\end{array}$ & $\begin{array}{c}0.00 \\
(0.00)\end{array}$ & $\begin{array}{c}0.00 \\
(0.00)\end{array}$ \\
\hline Company effects & $\begin{array}{c}0.00 \\
(0.00)\end{array}$ & $\begin{array}{c}0.00 \\
(0.00)\end{array}$ & $\begin{array}{c}0.00 \\
(0.00)\end{array}$ & $\begin{array}{c}0.00 \\
(0.00)\end{array}$ & $\begin{array}{c}0.00 \\
(0.00)\end{array}$ & $\begin{array}{c}0.00 \\
(0.00)\end{array}$ \\
\hline
\end{tabular}


Table 2. Cont.

\begin{tabular}{|c|c|c|c|c|c|c|}
\hline Control Variables and Independent and Moderating Variables & Model 1 & Model 2 & Model 3 & Model 4 & Model 5 & Model 6 \\
\hline \multicolumn{7}{|l|}{ Independent and moderating variables } \\
\hline Interlocks $(\mathrm{H} 1)$ & & $\begin{array}{l}0.04^{* *} \\
(0.02)\end{array}$ & $\begin{array}{l}0.03 * \\
(0.02)\end{array}$ & $\begin{array}{c}0.01 \\
(0.02)\end{array}$ & $\begin{array}{l}0.04 * \\
(0.02)\end{array}$ & $\begin{array}{l}0.14^{* *} \\
(0.06)\end{array}$ \\
\hline Politicians on board & & & $\begin{array}{c}0.00 \\
(0.00)\end{array}$ & $\begin{array}{c}-0.01^{* *} \\
(0.00)\end{array}$ & $\begin{array}{c}0.00 \\
(0.00)\end{array}$ & $\begin{array}{l}0.13^{* *} \\
(0.05)\end{array}$ \\
\hline Interlocks * Politicians on board (h2) & & & & $\begin{array}{c}0.00^{* * * *} \\
(0.00)\end{array}$ & & $\begin{aligned}-0.07^{* * *} & (0.02)\end{aligned}$ \\
\hline Degree of regulation & & & & & $\begin{array}{l}-0.09 \\
(0.14)\end{array}$ & $\begin{array}{c}0.35 \\
(0.32)\end{array}$ \\
\hline Interlocks * degree of regulation & & & & & & $\begin{array}{c}-0.14 * \\
(0.07)\end{array}$ \\
\hline Politicians on board * degree of regulation & & & & & & $\begin{array}{l}-0.14^{* * *} \\
(0.05)\end{array}$ \\
\hline Interlocks * Politicians on board * degree of regulation (h3) & & & & & & $\begin{array}{c}0.08^{* * *} \\
(0.02)\end{array}$ \\
\hline Observations & 479 & 479 & 479 & 479 & 479 & 479 \\
\hline R2 & 14.5 & 17.2 & 17.8 & 20.8 & 18.3 & 28.1 \\
\hline F Statistic & $3.07^{* * *}$ & $3.44^{* * *}$ & $3.16^{* * *}$ & $3.11^{* * *}$ & $2.86^{* * *}$ & $7.16^{* * *}$ \\
\hline
\end{tabular}

Note: number of observations $=479$. Robust standard errors are in parentheses. The table displays the ordinary least-squares (OLS) regression results using the scale in acquisitions as the dependent variable and interlocks, politicians on board and government control as independent variables. All regressions considered standard errors corrected by heteroscedasticity. ${ }^{*} p<$ $0.1 ; * * 0<0.05 ; * * * 0<0.01$ 


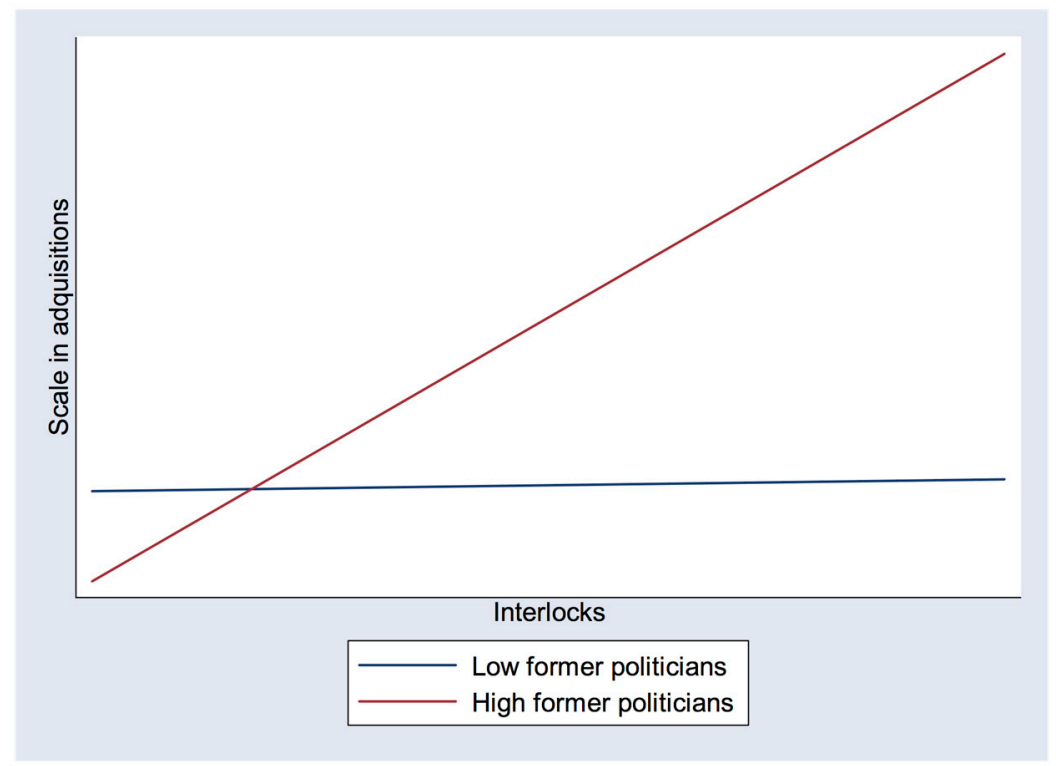

Figure 1. Moderating effect of politicians on boards on the positive relation between the interlocks and scale in acquisitions.

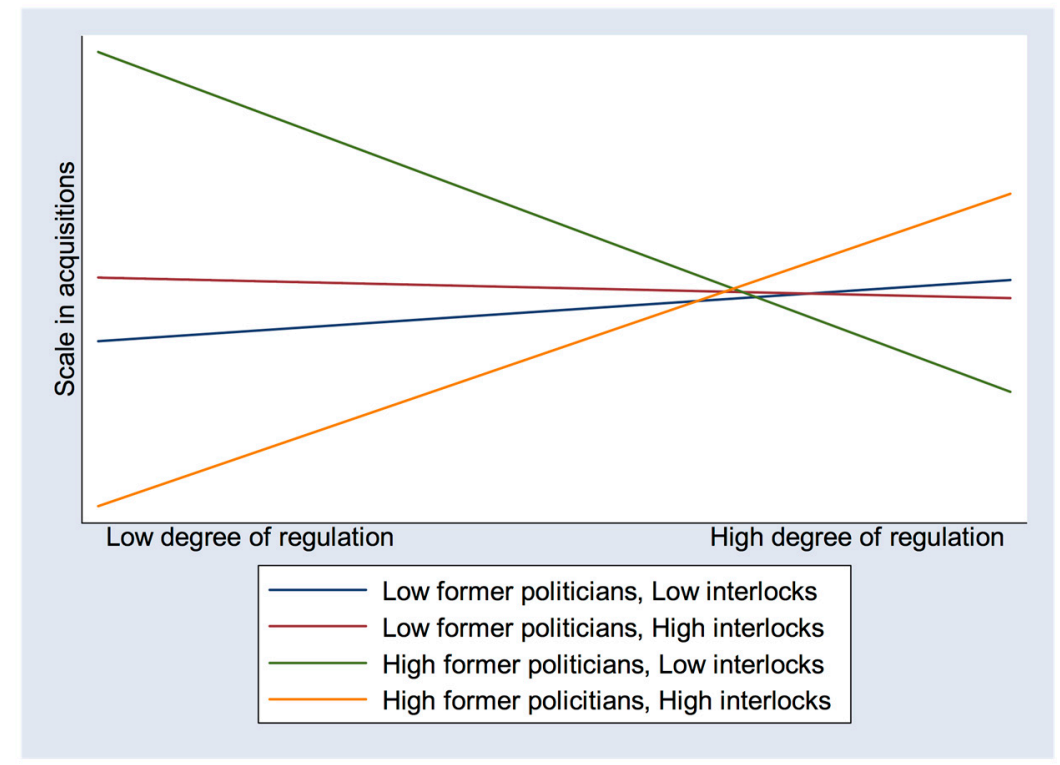

Figure 2. Three-way interactions: moderating effects of degree of regulation and politicians on boards on the relationship between interlocks and scale in acquisitions.

Table 3. Slope difference tests.

\begin{tabular}{ccc}
\hline Pair of Slopes & $\mathbf{t}$-Value for Slope Difference & $\boldsymbol{p}$-Value for Slope Difference \\
\hline (1) and (2) & -2.77 & 0.01 \\
(1) and (3) & -1.95 & 0.04 \\
(1) and (4) & 3.89 & 0.00 \\
$(2)$ and (3) & 2.70 & 0.01 \\
(2) and (4) & 3.72 & 0.00 \\
(3) and (4) & 3.91 & 0.00 \\
\hline
\end{tabular}

\section{Discussion and Conclusions}

Despite an increasing uncertainty and a substantial decrease in takeover activity during the financial crisis, acquisitions reached new heights all over the world by the year 2014 [22]. Resource Dependency 
Theory suggests that firms are dependent on external organizations, and this dependency creates risk and uncertainty [7]. Firms build networks to have access to timely information, to reduce uncertainty and, therefore, to be able to adapt to the external environment [105]. Based on this framework, we have analysed how organizations respond to resource dependencies by forming networks in the context of acquisitions. We also analysed how a specific resource, former politicians, can provide an edge in the acquisition process and how interlocks and former politicians are affected by regulation in the industry. Thus, we have examined the acquisition decision with regards to its scale, measured in terms of the acquisition value and the percentage of acquired shares. Previous studies analysing how corporate governance mechanisms affect acquisition have focused on a number of variables, such as financial variables and performance, higher announcement returns, or the number of connections among directors in the US [21]. Also, the impact of governance mechanisms on corporate takeovers [22], the position of the firms within the network and network centrality in China [27], toehold bidding and premiums in the US [19], abnormal announcement returns in the US [40], and acquiring-firm shareholder loses around acquisition announcements in the US [40] have been investigated. Within this corporate governance literature, there is a stream of research oriented towards the study of how the characteristics of the board [45], such as board independence [41,46,47], board size [48], board meetings, or board ownership, affect the propensity to acquire other firms [49]. In this research, we focused on the importance of interlocks and former politicians on firm acquisitions.

In our study, the first hypothesis proposes that those boards that are better connected (higher number of interlocks) will be associated with larger-scale acquisitions. There is a number of reasons, such as better access to information [17], helping bidders to identify targets, and the increase of likelihood in terms of acquisition completion [24], that can explain this behaviour. The results support this hypothesis. Our findings reveal that better connected boards with more board interlocks have an advantage over those boards without such ties. This fact leads to an increase with regards to acquisition scale, measured in terms of acquisition value and percentage of acquired shares. Our findings are in line with previous works $[21,53,106]$ that suggest that board interlocks are an important source of information for directors regarding acquisition decisions.

Former politicians and their contributions to the board have been studied, focusing on, for example, their linkages to other firms in the external environment [4], their ability to interpret regulation [79], and their interlock ties in regulated sectors $[79,80]$. The second hypothesis supports that former politicians and the interlocks they provide to the board will have a significant effect on the scale of acquisitions. Our results support this second hypothesis; that is, the relationship between interlocks and the scale of the acquisition is positively moderated by the presence of former politicians. In other words, the effects of direct interlock ties are amplified further when there are former politicians on boards. The incorporation of former politicians to the board may be seen as a firm strategy to establish links with the external environment and reduce acquisition uncertainty. This may also confirm the role that former politicians play as community influentials [74], given that they provide information and non-business perspectives on acquisition decisions, as well as networks with powerful stakeholders.

The third hypothesis introduces a new variable, regulation in the industry, and proposes that industries with high levels of regulation will make interlocked and politically experienced boards positively associated with large-scale acquisitions. Traditionally regulated industries include the utilities sector (mainly electricity) [65], banking and financial services [101,102], as well as the chemicals sector [103]. There is a three-way interaction between the degree of regulation, interlocked boards, and politically experienced boards, with an impact on the scale in acquisitions. The degree of government control in the industry increases the interaction effect between the interlocks variable and politicians on boards presented in Hypothesis 2. The results support this hypothesis. Indeed, our findings suggest that, in the case of regulated industries, a high number of board interlocks and a high number of former politicians involve positive effects on the scale of acquisitions. In other words, acquiring firms in industries that are highly regulated, and that include former politicians and 
a high number of interlocks, would be an advantage for the firm from the scale of acquisitions' point of view.

The analysis of the results also provides further insight into the relationship of these three variables. Although the best option is to have high levels of both (i.e., interlocks and former politicians on the board), it seems that the role played by interlocks is more important than that of former politicians on the board. Theoretically, we contend that the prospects for effective acquisitions depend to a great extent on the director's ability to design an economic agreement that passes regulatory barriers, and, in this sense, we support that former politicians play a critical role. However, it seems that under highly regulated industries, board interlocks can replace other formal methods of acquiring information such as those provided by former politicians. This result highlights the importance of board interlocks in acquisition decisions and the special attention that they deserve, and that previous literature has not acknowledged so far.

The overall conclusion of this research is that better connected boards (with higher board interlocks and former politicians as directors) have an informational advantage over those boards without such ties, and this leads to more willingness to acquire. Also, our results show that under highly regulated conditions, these informational advantages are even more advantageous to make decisions on acquisitions.

Our research presents a number of contributions. First, the literature on interlocks [21,28], on former politicians on boards $[25,30,33]$, and on acquisitions has generally been addressed separately. The literature on corporate governance has suggested that the use of board interlocks may be a corporate board mechanism used to gain access to other companies [3] and to obtain more accurate information [107], which improves firm performance [6]. Former politicians not only possess unique knowledge of the practices of various regulators, but they also make the acquisition processes more attractive to the company [25]. By using a holistic perspective in our analysis, we are able to provide a better understanding of the influence of inter-firm board networks on acquisition decisions, suggesting which characteristics of the board (in terms of board interlocks and political connections) can provide useful information and access to outside stakeholders (i.e., other companies and the government) for firms making decisions. The lack of research in this specific area prompted us to undertake this research.

A second contribution is related to the uniqueness of Spain and the continental model. Previous studies on board networks have mostly been carried out within the Anglo-American context or have adopted an international perspective. This fact may have influenced the interpretation of the results because of the existing legal, judicial, and cultural differences across countries [34-37]. As Aguilera [108] argues, the industrialisation process defined the role of banks and their relation with other private business. Europe, in particular, has two different models: on the one hand, the Anglo-Saxon model, in which capital accumulation is self-financed. Great Britain is a leading example. On the other hand, the continental model, with Germany as an example, had to rely on foreign capital or banks for financing [108]. As a consequence, firms and their relationships with banks and their interlocks are going to differ. For example, within the Anglo-Saxon model, the US has a number of laws (Clayton Act, Sherman Act) that, for example, provide severe anti-trust laws and declare interlocks among competing firms illegal, whereas the continental model leads to banks influencing corporate affairs [108]. To date, there are very few studies conducted in Spain, and they are focused on the link between political connections and compensation policies in saving banks, the informativeness of accounting earnings [38], as well as on the study of hiring influential former politicians in the revolving doors [39]. In turn, there are no studies on the relationship between interlocks, former politicians, regulations, and acquisitions. This, combined with the uniqueness of the continental model, deserves the present analysis.

A third contribution in our research is related to the construct and the variables used. We analysed the acquisition decision with regards to its scale, measured in terms of the acquisition value and the percentage of acquired shares. Most of the studies analysing how corporate governance mechanisms affect acquisitions have focused on financial outcomes (e.g., deal announcements on abnormal 
returns) $[19,22,27,40,42]$. We purposely chose not to focus on the financial aspects of the acquisition but rather, following Resource Dependence Theory, on how possessing specific resources, interlocks, and former politicians will provide an advantage over those boards without such ties, and how it leads to a higher acquisition scale, measured in terms of acquisition value and percentage of acquired shares. After all, firms are interest driven [109] and strive for survival and continuous success [110,111]. Financial gains might be the goal, but there are different paths to achieve such goal. We focused on one of these less travelled paths.

This research involves a number of managerial implications. Nowadays, acquisitions represent one of the major managerial investment decisions. In this research, we confirm the importance of board networks, and we suggest which board characteristics, in terms of board connections, are crucial for the acquisition strategy. More so, we conclude that board interlocks and former politicians increase the needed resources to create value in acquisition operations, especially in regulated industries. Following Resource Dependence Theory [7], the procurement of external resources is vital for the survival of the firm. We consider both interlocks and former politicians as external resources that will affect the behaviour of the firm and, more specifically, the scale of the acquisition. In line with this, firms should consider board composition carefully to ensure that certain interlocking directorate networks and board profiles have been co-opted into the board when considering large-scale acquisition decisions. Better informed boards can make better decisions, and interlocks and former politicians are a relevant factor to consider in this respect.

In the last two decades we have faced a number of waves of deregulation and privatisation all over the world, but there are still a number of industries that are highly regulated. Our research also suggests that government policies still have a great impact on firm operations, as other authors have previously confirmed (e.g., Hillman, [31]). Increasing the number of interlocks the board has is, therefore, a strategy that firms follow to manage this regulation. We also find that, as regulation increases in the industry, former politicians play a less relevant role, while interlocks take prominence.

This study presents some limitations and also provides insight into further lines of study. Our research has only selected acquisitions of large companies in Spain quoted on the stock exchange market, which have the duty to comply with legislation and publish data related to corporate governance, performance, and several control variables. We believe that it is necessary, and would be of great interest, to continue research in this field, incorporating information from other companies, and not only those that are quoted on the continuous market. Firms of all sizes are involved in acquisitions. The way in which firm size affects acquisition decisions might vary according to the type of organisation being studied. Likewise, further analysis in other European countries should be undertaken, and the results should be compared. Besides, whether every country with a continental model behaves in a similar way is something that is yet to be explored. Likewise, we do not know to what extent there are significant behaviour differences between countries using a continental model and those using the Anglo-Saxon model. In line with this, it is known that not all countries in Europe have the same level of industrialisation. For example, Spain was a late-comer to industrialisation in Europe, and within the European Union, with the last major enlargement of 2004, it would be interesting to analyse how firms in different countries with different levels of industrialisation use interlocks and former politicians when considering large-scale acquisitions.

Although we have controlled for certain variables, such as industry, future investigations should seek a broader firm sample and include non-profit companies or family firms [112]. The two main variables we used (i.e., interlocks and former politicians) also present some limitations, which can also be used as further lines of study. For example, we neither controlled for the busyness effect (i.e., when directors serve on three or more boards) nor whether busy board members may have led to poor firm performance [113]. Some studies reveal that directors only have a limited amount of time and resources to perform their roles. Thus, directors with multiple board seats would potentially be a non-effective monitor and advisor given the time constraints on their schedule. Other studies have noted that social ties between the merging firm directors lead to familiarity bias in terms of decision 
making, which outweighs the positive effect of improved information sharing [53]. The literature seems to suggest a curvilinear (instead of linear) relationship between social networks and acquisitions. Further research is needed in this respect. Other potential non-positive effects of interlocks include the loss of firm value [114] or reputational penalties, that is, being related through interlocks to firms alleged with financial reporting fraud [115]. Similarly, the literature on "revolving doors" shows, among other issues, that longevity in a cabinet position matters [63]. Prior research indicates that the benefits of political connections are directly related to the strength of the political connection, measured basically with two dimensions: (1) whether the politician's political party is in power [116-118] and/or (2) the political experience of the appointee [32,63]. None of these variables has been considered in this research, as we only measured the existence or absence of former politicians on boards. This would be, however, an interesting research path for the development of future studies. Further analysis should also be undertaken to control for political tenure. Finally, further lines of study should focus on family firms given that, while the literature includes both interlocks and former politicians, they have not been examined together within the same study.

Author Contributions: Conceptualization, G.C.-R. and L.P.-C.; Data curation, S.K. and L.P.-C.; Formal analysis, L.P.-C.; Investigation, S.K.; Methodology, S.K., G.C.-R. and L.P.-C.; Supervision, G.C.-R.; Writing-original draft, G.C.-R. and L.P.-C.; Writing - review \& editing, S.K. and G.C.-R. All authors have read and agreed to the published version of the manuscript.

Conflicts of Interest: The authors declare no conflict of interest.

\section{References}

1. Mizruchi, M.S. What Do Interlocks Do? An Analysis, Critique, and Assessment of Research on Interlocking Directorates. Annu. Rev. Sociol. 1996, 22, 271-298. [CrossRef]

2. Caiazza, R.; Simoni, M. Directorate ties: A bibliometric analysis. Manag. Decis. 2019, 57, 2837-2851. [CrossRef]

3. Lester, R.H.; Hillman, A.; Zardkoohi, A.; Cannella, A.A. Former Government Officials as Outside Directors: The Role of Human and Social Capital. Acad. Manag. J. 2008, 51, 999-1013. [CrossRef]

4. Shropshire, C. The Role of Interlocking Director and Board Receptivity in the Diffusion of Practices. Acad. Manag. Rev. 2010, 35, 246-264.

5. Acquaah, M. Managerial social capital, strategic orientation, and organizational performance in an emerging economy. Strat. Manag. J. 2007, 28, 1235-1255. [CrossRef]

6. Kim, Y.; Cannella, A.A. Toward a Social Capital Theory of Director Selection. Corp. Governance: Int. Rev. 2008, 16, 282-293. [CrossRef]

7. Pfeffer, J.; Salancik, G. The External Control of Organizations: A Resource Dependence Perspective; Harper: New York, NY, USA, 1978.

8. Westphal, J.D.; Zajac, E.J. Decoupling Policy from Practice: The Case of Stock Repurchase Programs. Adm. Sci. Q. 2001, 46, 202. [CrossRef]

9. Yoshikawa, T.; Shim, J.W.; Kim, C.H.; Tuschke, A. How do board ties affect the adoption of new practices? The effects of managerial interest and hierarchical power. Corp. Govern. Int. Rev. 2020, 28, 2-22. [CrossRef]

10. Haunschild, P.R. Interorganizational Imitation: The Impact of Interlocks on Corporate Acquisition Activity. Adm. Sci. Q. 1993, 38, 564. [CrossRef]

11. Westphal, J.D.; Zajac, E.J. Defections from the Inner Circle: Social Exchange, Reciprocity, and the Diffusion of Board Independence in U.S. Corporations. Adm. Sci. Q. 1997, 42, 161. [CrossRef]

12. Mazzola, E.; Perrone, G.; Kamuriwo, D.S. The interaction between inter-firm and interlocking directorate networks on firm's new product development outcomes. J. Bus. Res. 2016, 69, 672-682. [CrossRef]

13. Li, M. Diversity of Board Interlocks and the Impact on Technological Exploration: A Longitudinal Study. J. Prod. Innov. Manag. 2019, 36, 490-512. [CrossRef]

14. Zou, H.; Xie, X.; Meng, X.; Yang, M. The diffusion of corporate social responsibility through social network ties: From the perspective of strategic imitation. Corp. Social Responsibility Environ. Manage. 2019, 26, 186-198. [CrossRef] 
15. Davis, G.F. Agents without Principles? The Spread of the Poison Pill through the Intercorporate Network. Adm. Sci. Q. 1991, 36, 583. [CrossRef]

16. Brandes, P.; Hadani, M.; Goranova, M. Stock options expensing: An examination of agency and institutional theory explanations. J. Bus. Res. 2006, 59, 595-603. [CrossRef]

17. Gulati, R.; Westphal, J.D. Cooperative or Controlling? The Effects of CEO-Board Relations and the Content of Interlocks on the Formation of Joint Ventures. Adm. Sci. Q. 1999, 44, 473. [CrossRef]

18. Palmer, D.A.; Jennings, P.D.; Zhou, X. Late Adoption of the Multidivisional Form by Large U.S. Corporations: Institutional, Political, and Economic Accounts. Adm. Sci. Q. 1993, 38, 100. [CrossRef]

19. Betton, S.; Eckbo, B.E.; Thorburn, K.S. Merger negotiations and the toehold puzzle. J. Financ. Econ. 2009, 91, 158-178.

20. Singh, P.V.; Schonlau, R.J. Board Networks and Merger Performance (September 8, 2009). Available online: https://ssrn.com/abstract=1322223 (accessed on 25 January 2020).

21. Cai, Y.; Sevilir, M. Board connections and M\&A transactions. J. Financ. Econ. 2012, 103, 327-349.

22. Aktas, N.; Croci, E.; Simsir, S.A. Corporate Governance and Takeover Outcomes. Corp. Govern. 2016, 24, 242-252. [CrossRef]

23. Haunschild, P.R. How Much is That Company Worth?: Interorganizational Relationships, Uncertainty, and Acquisition Premiums. Adm. Sci. Q. 1994, 39, 391. [CrossRef]

24. Renneboog, L.; Zhao, Y. Director networks and takeovers. J. Corp. Financ. 2014, 28, 218-234. [CrossRef]

25. Ferris, S.P.; Houston, R.; Javakhadze, D. Friends in the right places: The effect of political connections on corporate merger activity. J. Corp. Financ. 2016, 41, 81-102. [CrossRef]

26. Lamb, N.H.; Roundy, P. The "ties that bind" board interlocks research: A systematic review. Manag. Res. Rev. 2016, 39, 1516-1542. [CrossRef]

27. Tao, Q.; Li, H.; Wu, Q.; Zhang, T.; Zhu, Y. The dark side of board network centrality: Evidence from merger performance. J. Bus. Res. 2019, 104, 215-232. [CrossRef]

28. Haunschild, P.R.; Beckman, C.M. When Do Interlocks Matter?: Alternate Sources of Information and Interlock Influence. Adm. Sci. Q. 1998, 43, 815. [CrossRef]

29. Drees, J.M.; Heugens, P.P.M.A.R. Synthesizing and Extending Resource Dependence Theory: A Meta-Analysis. J. Manag. 2013, 39, 1666-1698. [CrossRef]

30. Greve, H.R.; Zhang, C.M. Institutional Logics and Power Sources: Merger and Acquisition Decisions. Acad. Manag. J. 2017, 60, 671-694. [CrossRef]

31. Hillman, A.J. Politicians on the Board of Directors: Do Connections Affect the Bottom Line? J. Manag. 2005, 31, 464-481. [CrossRef]

32. Gray, S.; Harymawan, I.; Nowland, J. Political and government connections on corporate boards in Australia: Good for business? Aust. J. Manag. 2014, 41, 3-26. [CrossRef]

33. Devine, R.; Lamont, B.T.; Harris, R.J. Managerial Control in Mergers of Equals: The Role of Political Skill. J. Manag. Issues 2016, 28, 50-66. [CrossRef]

34. Phan, P.H.; Lee, S.H.; Lau, S.H. The Performance Impact of Interlocking Directorates: The Case of Singapore. J. Manag. Issues 2003, 15, 338-352.

35. Miller, G.S. Discussion of What Determines Corporate Transparency? J. Account. Res. 2004, 42, $253-268$. [CrossRef]

36. Gul, F.A. Auditors' Response to Political Connections and Cronyism in Malaysia. J. Account. Res. 2006, 44, 931-963. [CrossRef]

37. King, M.R.; Santor, E. Family values: Ownership structure, performance and capital structure of Canadian firms. J. Bank. Financ. 2008, 32, 2423-2432. [CrossRef]

38. Bona-Sánchez, C.; Pérez-Alemán, J.; Santana-Martín, D.J. Politically Connected Firms and Earnings Informativeness in the Controlling versus Minority Shareholders Context: European Evidence. Corp. Gov. Int. Rev. 2014, 22, 330-346. [CrossRef]

39. Albalate, D.; Bel, G.; González-Gómez, F.; Picazo-Tadeo, A.J. Weakening political connections by means of regulatory reform: Evidence from contracting out water services in Spain. J. Regul. Econ. 2017, 52, 211-235. [CrossRef]

40. Moeller, S.B.; Schlingemann, F.P.; Stulz, R.M. Firm size and the gains from acquisitions. J. Financ. Econ. 2004, 73, 201-228. [CrossRef] 
41. Desai, A.; Kroll, M.; Wright, P. Outside board monitoring and the economic outcomes of acquisitions: A test of the substitution hypothesis. J. Bus. Res. 2005, 58, 926-934. [CrossRef]

42. Moeller, S.B.; Schlingemann, F.P.; Stulz, R.M. Wealth Destruction on a Massive Scale? A Study of Acquiring-Firm Returns in the Recent Merger Wave. J. Financ. 2005, 60, 757-782. [CrossRef]

43. Mitchell, M.L.; Mulherin, J. The impact of industry shocks on takeover and restructuring activity. J. Financ. Econ. 1996, 41, 193-229. [CrossRef]

44. Harford, J. What drives merger waves? J. Financ. Econ. 2005, 77, 529-560. [CrossRef]

45. Redor, E. Board attributes and shareholder wealth in mergers and acquisitions: A survey of the literature. J. Manag. Govern. 2016, 20, 789-821. [CrossRef]

46. Walters, B.A.; Kroll, M.J.; Wright, P. CEO tenure, boards of directors, and acquisition performance. J. Bus. Res. 2007, 60, 331-338. [CrossRef]

47. Yang, M. Ownership participation of cross-border mergers and acquisitions by emerging market firms. Manag. Decis. 2015, 53, 221-246. [CrossRef]

48. Goranova, M.; Dharwadkar, R.; Brandes, P. Owners on both sides of the deal: Mergers and acquisitions and overlapping institutional ownership. Strat. Manag. J. 2010, 31, 1114-1135. [CrossRef]

49. Chatterji, A.K.; Findley, M.; Jensen, N.M.; Meier, S.; Nielson, D. Field experiments in strategy research. Strat. Manag. J. 2016, 37, 116-132. [CrossRef]

50. Robinson, S. The Mergers \& Acquisitions Review; Law Business Research Ltd: London, UK, 2011.

51. Simpson, S.; Hopkins, S. Mergers E Acquisitions: Spain; Global Legal Insights: Madrid, Spain, 2019.

52. Prakash, S.; Bolotnikova, I. The Deloitte MEA Index 2016; Opportunities Amidst Divergence: London, UK, 2016.

53. Ishii, J.; Xuan, Y. Acquirer-target social ties and merger outcomes. J. Financ. Econ. 2014, 112, $344-363$. [CrossRef]

54. Güner, A.B.; Malmendier, U.; Tate, G. Financial expertise of directors. J. Financ. Econ. 2008, 88, 323-354. [CrossRef]

55. Huang, Q.; Jiang, F.; Lie, E.; Yang, K. The role of investment banker directors in M\&A. J. Financ. Econ. 2014, 112, 269-286.

56. Bruner, R. Where M\&A Pays and Where It Strays: A Survey of the Research. J. Appl. Corp. Financ. 2004, 16, 63-76.

57. Akerlof, G.A. The Market for "Lemons": Quality Uncertainty and the Market Mechanism*. Q. J. Econ. 1970, 84, 488. [CrossRef]

58. Myers, S.C.; Majluf, N.S. Corporate financing and investment decisions when firms have information that investors do not have. J. Financ. Econ. 1984, 13, 187-221. [CrossRef]

59. Beckman, C.M.; Haunschild, P.R. Network Learning: The Effects of Partners' Heterogeneity of Experience on Corporate Acquisitions. Adm. Sci. Q. 2002, 47, 92. [CrossRef]

60. Stuart, T.E.; Yim, S. Board interlocks and the propensity to be targeted in private equity transactions. J. Financ. Econ. 2010, 97, 174-189. [CrossRef]

61. Basuil, D.A.; Datta, D.K. Value creation in cross-border acquisitions: The role of outside directors' human and social capital. J. Bus. Res. 2017, 80, 35-44. [CrossRef]

62. Pascual-Fuster, B.; Crespí-Cladera, R. Politicians in the boardroom: Is it a convenient burden? Corp. Governance: Int. Rev. 2018, 26, 448-470. [CrossRef]

63. Houston, R.; Ferris, S. Does the revolving door swing both ways? The value of political connections to US firms. Manag. Financ. 2015, 41, 1002-1031. [CrossRef]

64. Charles, J.C.; Yuan, D.; Chansog, K. High-level politically connected firms, corruption, and analyst forecast accuracy around the world. J. Int. Bus. Stud. 2010, 41, 1505.

65. Agrawal, A.; Knoeber, C.R. Do Some Outside Directors Play a Political Role? J. Law Econ. 2001, 44, $179-198$. [CrossRef]

66. Goldman, E.; Rocholl, J.; So, J. Do Politically Connected Boards Affect Firm Value? Rev. Financ. Stud. 2009, 22, 2331-2360. [CrossRef]

67. Faccio, M. Politically Connected Firms. Am. Econ. Rev. 2006, 96, 369-386. [CrossRef]

68. Khwaja, A.I.; Mian, A. Do Lenders Favor Politically Connected Firms? Rent Provision in an Emerging Financial Market. Q. J. Econ. 2005, 120, 1371-1411. [CrossRef] 
69. Yeh, Y.-H.; Shu, P.-G.; Chiu, S.-B. Political connections, corporate governance and preferential bank loans. Pac. Basin Financ. J. 2013, 21, 1079-1101. [CrossRef]

70. Cooper, M.J.; Gülen, H.; Ovtchinnikov, A.V. Corporate Political Contributions and Stock Returns. J. Financ. 2010, 65, 687-724. [CrossRef]

71. Amore, M.D.; Bennedsen, M. The value of local political connections in a low-corruption environment. J. Financ. Econ. 2013, 110, 387-402. [CrossRef]

72. Niessen, A.; Ruenzi, S. Political Connectedness and Firm Performance: Evidence from Germany. Ger. Econ. Rev. 2010, 11, 441-464. [CrossRef]

73. García-Meca, E.; Palacio, C.J. Board composition and firm reputation: The role of business experts, support specialists and community influentials. BRQ Bus. Res. Q. 2018, 21, 111-123. [CrossRef]

74. Hillman, A.J.; Cannella, A.A.; Paetzold, R.L. The Resource Dependence Role of Corporate Directors: Strategic Adaptation of Board Composition in Response to Environmental Change. J. Manag. Stud. 2000, 37, $235-256$. [CrossRef]

75. Stratmann, T. Can Special Interests Buy Congressional Votes? Evidence from Financial Services Legislation. J. Law Econ. 2002, 45, 345-373. [CrossRef]

76. Hillman, A.J.; Keim, G.D.; Schuler, D. Corporate Political Activity: A Review and Research Agenda. J. Manag. 2004, 30, 837-857. [CrossRef]

77. Cornaggia, J.; Cornaggia, K.J.; Xia, H. Revolving doors on Wall Street. J. Financ. Econ. 2016, 120, 400-419. [CrossRef]

78. Hillman, A.J.; Hitt, M.A. Corporate Political Strategy Formulation: A Model of Approach, Participation, and Strategy Decisions. Acad. Manag. Rev. 1999, 24, 825-842. [CrossRef]

79. Luo, Y. Industrial dynamics and managerial networking in an emerging market: The case of China. Strat. Manag. J. 2003, 24, 1315-1327. [CrossRef]

80. Kaczmarek, S.; Kimino, S.; Pye, A. Interlocking directorships and firm performance in highly regulated sectors: The moderating impact of board diversity. J. Manag. Govern. 2014, 18, 347-372. [CrossRef]

81. Helland, E.; Sykuta, M. Regulation and the Evolution of Corporate Boards: Monitoring, Advising, or Window Dressing? J. Law Econ. 2004, 47, 167-193. [CrossRef]

82. Hadani, M.; Schuler, D.A. In search of El Dorado: The elusive financial returns on corporate political investments. Strat. Manag. J. 2013, 34, 165-181. [CrossRef]

83. Stark, D.; Vedres, B. Political Holes in the Economy: The Business Network of Partisan Firms in Hungary (translated by Alexander Kurakin). J. Econ. Sociol. 2012, 13, 19-47. [CrossRef]

84. Bonardi, J.-P.; Hillman, A.J.; Keim, G.D. The Attractiveness of Political Markets: Implications for Firm Strategy. Acad. Manag. Rev. 2005, 30,397-413. [CrossRef]

85. Boubakri, N.; Guedhami, O.; Mishra, D.; Saffar, W. Political connections and the cost of equity capital. J. Corp. Financ. 2012, 18, 541-559. [CrossRef]

86. Jensen, M.C. The Modern Industrial Revolution, Exit, and the Failure of Internal Control Systems. J. Financ. 1993, 48, 831-880. [CrossRef]

87. Hillman, A.J.; Dalziel, T. Boards of Directors and Firm Performance: Integrating Agency and Resource Dependence Perspective. Acad. Manag. Rev. 2003, 28, 383-396. [CrossRef]

88. Daily, C.M.; Dalton, D.R.; Cannella, A.A. Corporate Governance: Decades of Dialogue and Data. Acad. Manag. Rev. 2003, 28, 371-382. [CrossRef]

89. Stevenson, W.B.; Radin, R.F. Social Capital and Social Influence on the Board of Directors. J. Manag. Stud. 2009, 46, 16-44. [CrossRef]

90. Fracassi, C.; Tate, G. External Networking and Internal Firm Governance. J. Financ. 2012, 67, $153-194$. [CrossRef]

91. Pearce, J.A.; Zahra, S.A. Board Composition from a Strategic Contingency Perspective. J. Manag. Stud. 1992, 29, 411-438. [CrossRef]

92. Fraile, A.I.; Fradejas, N.A. Ownership structure and board composition in a high ownership concentration context. Eur. Manag. J. 2014, 32, 646-657. [CrossRef]

93. Jensen, M.C.; Meckling, W.H. Theory of the firm: Managerial behavior, agency costs and ownership structure. J. Financ. Econ. 1976, 3, 305-360. [CrossRef]

94. Fama, E.F.; Jensen, M.C. Separation of Ownership and Control. J. Law Econ. 1983, 26, 301-325. [CrossRef] 
95. Combs, J.G.; Ketchen, D.J.; Perryman, A.A.; Donahue, M.S. The Moderating Effect of CEO Power on the Board Composition? Firm Performance Relationship. J. Manag. Stud. 2007, 44. [CrossRef]

96. Kor, Y.Y.; Sundaramurthy, C. Experience-Based Human Capital and Social Capital of Outside Directors. J. Manag. 2008, 35, 981-1006. [CrossRef]

97. Faleye, O.; Hoitash, R.; Hoitash, U. The costs of intense board monitoring. J. Financ. Econ. 2011, 101, $160-181$. [CrossRef]

98. Haynes, K.T.; Hillman, A. The effect of board capital and CEO power on strategic change. Strat. Manag. J. 2010, 31, 1145-1163. [CrossRef]

99. Wincent, J.; Anokhin, S.; Örtqvist, D. Does network board capital matter? A study of innovative performance in strategic SME networks. J. Bus. Res. 2010, 63, 265-275. [CrossRef]

100. Pombo, C.; Gutierrez, L.H. Outside directors, board interlocks and firm performance: Empirical evidence from Colombian business groups. J. Econ. Bus. 2011, 63, 251-277. [CrossRef]

101. Edwards, F.R. Managerial Objectives in Regulated Industries: Expense-Preference Behavior in Banking. J. Polit. Econ. 1977, 85, 147-162. [CrossRef]

102. Okhmatovskiy, I. Performance Implications of Ties to the Government and SOEs: A Political Embeddedness Perspective. J. Manag. Stud. 2010, 47, 1020-1047. [CrossRef]

103. Blau, G.; Mehta, B.; Bose, S.; Pekny, J.; Sinclair, G.; Keunker, K.; Bunch, P. Risk management in the development of new products in highly regulated industries. Comput. Chem. Eng. 2000, 24, 659-664. [CrossRef]

104. Williams, R. Using the Margins Command to Estimate and Interpret Adjusted Predictions and Marginal Effects. Stata J. Promot. Commun. Stat. Stata 2012, 12, 308-331. [CrossRef]

105. Pfeffer, J. Size and Composition of Corporate Boards of Directors: The Organization and its Environment. Adm. Sci. Q. 1972, 17, 218. [CrossRef]

106. Kale, P.; Singh, H.; Perlmutter, H. Learning and Protection of Proprietary Assets in Strategic Alliances: Building Relational Capital. Strat. Manag. J. 2000, 21, 217-237. [CrossRef]

107. Goranova, M.L.; Priem, R.L.; Ndofor, H.A.; Trahms, C.A. Is there a "Dark Side" to Monitoring? Board and Shareholder Monitoring Effects on M\&A Performance Extremeness. Strat. Manag. J. 2017, 38, 2285-2297.

108. Aguilera, R.V. Directorship Interlocks in Comparative Perspective: The Case of Spain. Eur. Sociol. Rev. 1998, 14, 319-342. [CrossRef]

109. Oliver, C. Strategic Responses to Institutional Processes. Acad. Manag. Rev. 1991, 16, 145-179. [CrossRef]

110. Dacin, T.; Oliver, C.; Roy, J.P. The Legitimacy of Strategic Alliances: An Institutional Perspective. Strat. Manag. J. 2007, 28, 169-187. [CrossRef]

111. Adams, R.B.; E Hermalin, B.; Weisbach, M.S. The Role of Boards of Directors in Corporate Governance: A Conceptual Framework and Survey. J. Econ. Lit. 2010, 48, 58-107. [CrossRef]

112. Forbes, D.; Milliken, F. Cognition and Corporate Governance: Understanding Boards of Directors as Strategic Decision-Making Groups. Acad. Manag. Rev. 1999, 24, 489. [CrossRef]

113. Fich, E.M.; Shivdasani, A. Are Busy Boards Effective Monitors? J. Financ. 2006, 61, 689-724. [CrossRef]

114. Subrahmanyam, A. Social Networks and Corporate Governance. Eur. Financ. Manag. 2008, 14, $633-662$. [CrossRef]

115. Kang, E. Director Interlocks and Spillover Effects of Reputational Penalties from Financial Reporting Fraud. Acad. Manag. J. 2008, 51, 537-555. [CrossRef]

116. Fisman, R. Estimating the Value of Political Connections. Am. Econ. Rev. 2001, 91, 1095-1102. [CrossRef]

117. Leuz, C.; Oberholzergee, F. Political relationships, global financing, and corporate transparency: Evidence from Indonesia. J. Financ. Econ. 2006, 81, 411-439. [CrossRef]

118. Mitchell, H.; Joseph, S. Changes in Malaysia: Capital controls, prime ministers and political connections. Pac. Basin Financ. J. 2010, 18, 460-476. [CrossRef]

(C) 2020 by the authors. Licensee MDPI, Basel, Switzerland. This article is an open access article distributed under the terms and conditions of the Creative Commons Attribution (CC BY) license (http://creativecommons.org/licenses/by/4.0/). 